\title{
Distinct responses of East Asian summer and winter monsoons to astronomical forcing
}

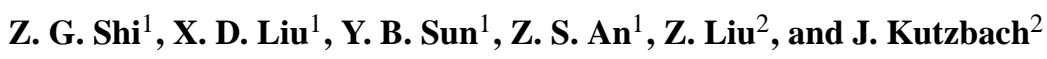 \\ ${ }^{1}$ SKLLQG, Institute of Earth Environment, Chinese Academy of Sciences, Xi' an, China \\ ${ }^{2}$ Center for Climatic Research, University of Wisconsin-Madison, Madison, Wisconsin, USA \\ Received: 30 December 2010 - Published in Clim. Past Discuss.: 7 March 2011 \\ Revised: 21 October 2011 - Accepted: 5 November 2011 - Published: 12 December 2011
}

\begin{abstract}
Influences of the Earth's astronomical forcing on the evolution of East Asian monsoon have been demonstrated with various geological records and climate models. Here, we present time series of climatic proxies from the Chinese Loess Plateau and Sanbao/Hulu caves and the winter/summer monsoon intensity index from a long-term transient climate model simulation. Both the observations and modelling results reveal consistently distinct responses of East Asian summer and winter monsoons to astronomical forcing. Different from the dominant local impact on the summer monsoon at the precession scale $(\sim 20 \mathrm{ka}$ period), the East Asian winter monsoon is driven predominantly by the obliquity forcing ( $\sim 40 \mathrm{ka}$ period). We propose that the obliquity forcing controls the meridional insolation difference and, therefore, exerts a more significant effect on the evolution of the East Asian winter monsoon than previously expected.
\end{abstract}

\section{Introduction}

The development of East Asian monsoon (EAM) is closely linked to global climate change and exerts a profound influence on living environments in the most populous regions in the world. The seasonal reversal in the regional atmospheric circulation is traditionally considered to be driven by the ocean-land thermal contrasts, which is resulted from the seasonal variations of solar radiation. According to modern monsoon theory (Wang, 2006), the robust Siberian high, a heat-driven high-pressure cell, widely occupies inland regions in the Eurasian continent and draws cold-dry northwesterly outflows from the Asian continental interior during

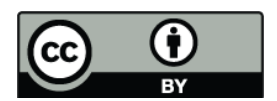

Correspondence to: Z. G. Shi

(shizg@ieecas.cn) winter seasons, inducing an arid environment in Northern China. While in summer, the monsoon is anchored by the Asian Low and brings abundant vapour mainly from the Northwest Pacific and plentiful rainfall in East Asia (Fig. 1).

The EAM reconstructions on the geological timescale will help much to understand how the EAM evolves in the past and provide useful information for the prediction for the future and has already attracted many researchers' attention (e.g., Ding et al., 1992; An et al., 2001; Wang et al., 2005). The evolution of EAM, including the summer and winter monsoons, has long been accepted as being well documented in the eolian deposits on the Chinese Loess Plateau (An et al., 1991; An, 2000). Recently, the stalagmite oxygen isotope records with absolute-dating from caves have provided highresolution variability of the summer monsoon (Yuan et al., 2004; Wang et al., 2008). The EAM system is fundamentally influenced by the astronomical scale in both direct insolation forcing and variations in global ice volume (Yin et al., 2009). In the last 800000 years, a strong 100-ka period consistent with global ice volume cycles is clearly found in the grain size records of Chinese loess, which indicates that the EAM system might be dominated by the changes in glacialage boundary conditions (Ding et al., 1995).

Since debates still exist as to the mechanisms how the glacial cycles occur (Hays et al., 1976), researchers generally focus on the precession and obliquity periodic bands when evaluating the effect from astronomical insolation. Some studies argue that global climate responds linearly to astronomical-driven variation in radiation budget on these two bands (Imbrie et al., 1992) and the EAM development is associated with the local insolation in the Northern Hemisphere (NH) (Yuan et al., 2004; Wang et al., 2008). Owing to its dominant role in the daily insolation variation (Berger, 1978, 1988), precession has been widely emphasized as the key factor in the monsoon evolution (Clemens and Prell, 2003; Wang et al., 2008; Liu and Shi, 2009)

Published by Copernicus Publications on behalf of the European Geosciences Union. 


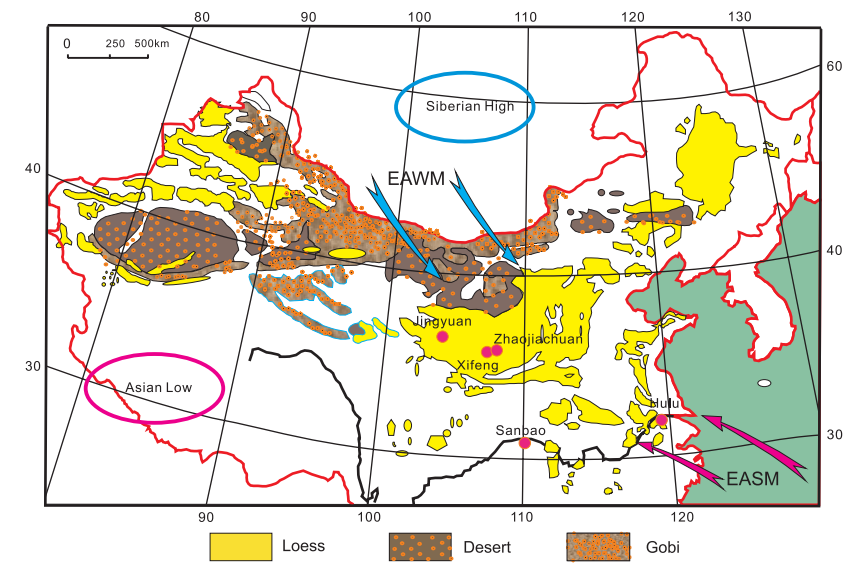

Fig. 1. Map showing the atmospheric circulation regime in East Asia and the locations of the sites of geological data used in this study. EASM - East Asian summer monsoon, EAWM - East Asian winter monsoon.

and "less-important" obliquity is often neglected. However, obliquity can control the total irradiation over a period of time during the year (Berger et al., 2010) and large-scale meridional gradient of insolation in the summer hemisphere (Tricot and Berger, 1988). Thus, how the astronomical parameters affect the EAM, especially the relative importance on these two bands, still needs to be clarified.

General circulation model (GCM) simulations are also widely applied to explain the evolution of Asian monsoon (e.g., Kutzbach, 1981; Braconnot et al., 2002; Liu et al., 2003). A large number of modelling studies simulate combined precession and obliquity signals in the monsoon systems, where precession dominates obliquity effects. Due to the huge computational costs of GCM operations, however, previous paleomonsoon experiments are equilibrium and focused on certain time-slices. For example, the Paleoclimate Modelling Intercomparison Project (PMIP) has only provided "snapshots" on climate in two special periods of $6 \mathrm{kaBP}$ and $21 \mathrm{kaBP}$. With the prescribed boundary conditions, e.g., the ice sheet and astronomical parameters, the climatic responses have been obtained after the models reach equilibrium. This restriction would lead to the absence of analyzing the long-term transient response of climate system and comparing it directly with the time series of geological climatic proxies. With the development of acceleration technique, it is possible for us to simulate the long-term continuous response of climate system to time-dependent astronomical forcing (Jackson and Broccoli, 2003; Lorenz and Lohmann, 2004). Especially, a 284-ka transient simulation with a fully-coupled ocean-atmosphere GCM has been employed recently in order to explore the effects of insolation (Kutzbach et al., 2007).

In this paper, the distinct responses of East Asian summer and winter monsoons to astronomical forcing (precession and obliquity) and the possible driving mechanisms are proposed. Two series of EAM proxies are employed to show the difference between summer and winter monsoons and the long-term evolutionary simulation results are analysed for further discussions. In Sect. 2, the EAM proxies and modelling results are first introduced. The responses of summer and winter monsoons and their mechanisms are analysed and discussed in Sects. 3 and 4, respectively. The main points are finally concluded in Sect. 5.

\section{Geological records and modelling data}

A set of high-resolution EAM variability records covering approximately the last two/three glaciation cycles are employed for this study. For the summer monsoon, the absolutedated speleothem oxygen isotope records from Sanbao and Hulu caves (Fig. 1) in Central China are chosen for the period of the past 224000 years (Wang et al., 2008). Fluctuations in the stalagmite $\delta^{18} \mathrm{O}$ largely reflect changes in $\delta^{18} \mathrm{O}$ values of atmospheric precipitation, and in turn, relates to changes in the summer monsoon strength (Yuan et al., 2004). Three grain size (GS) records of Chinese loess, which is widely used as a proxy for changes in the intensity of the East Asian winter monsoon (Xiao et al., 1992), are respectively from Jingyuan (Sun et al., 2006a), Xifeng-Changwu (Guo et al., 2009) and Zhaojiachuan (Sun et al., 2006b) sections (Fig. 1). The grain-size model (Porter and An, 1995) is used instead of the astronomical tuning method to calculate the age of successive stratigraphic layers to reduce the prescribed information about astronomical periods. To better explore the relative importance of precession and obliquity in the monsoon evolution, the 100-ka eccentricity component (greater than 67-ka) has already been filtered out.

Modelling outputs from a fast ocean-atmosphere model (FOAM) are employed to explore evolutionary responses of monsoon systems to astronomically-included changes of insolation (Kutzbach et al., 2007). FOAM is a fully coupled global ocean-atmosphere model, with a horizontal resolution of about $4^{\circ}$ latitude by $7.5^{\circ}$ longitude for atmosphere and $1.4^{\circ}$ latitude by $2.8^{\circ}$ longitude for ocean. In previous studies, FOAM has simulated well most major features of global monsoon systems without using flux adjustment (Liu et al., 2004). In order to accelerate long-term simulations, a wellvalidated astronomical forcing accelerating scheme is used (Jackson and Broccoli, 2003; Lorenz and Lohmann, 2004). With a factor of 100, FOAM was actually run for a length of 2840 simulated years after spin-up. That is, the astronomical parameters are advanced by 100 years at the end of each simulated year (Kutzbach et al., 2007). We restrict our focus to the atmosphere-upper ocean system. Since the response time of this system is much faster (about 1000 times) than the precession cycle, it allows us to extract the astronomical-scale changes from interannual variability in the model. Other boundary conditions, including the global ice sheets, are kept the same as the present day. Hence, the simulated variations 


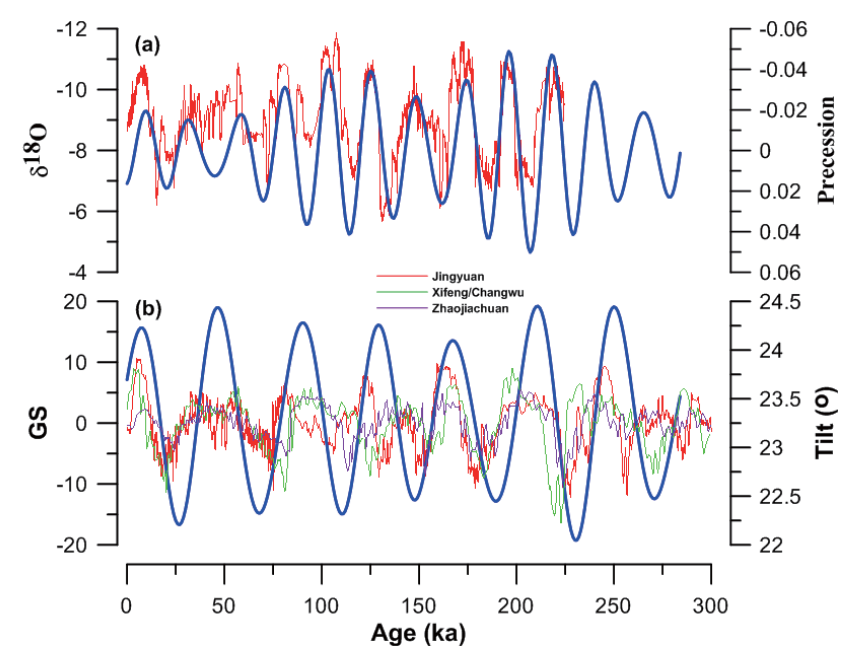

Fig. 2. Proxy records of East Asian monsoon evolution. (a) The absolute-dated stalagmite $\delta^{18} \mathrm{O}$ record from Sanbao and Hulu caves in Central China during the past $224 \mathrm{ka}$ (red). The parameter of precession is plotted for comparison (blue). (b) Three grain size records of Chinese loess from Jingyuan (red)/Xifeng-Changwu (green)/Zhaojiachuan (purple) sections covering the past $300 \mathrm{ka}$, plotted on arbitrary scale. The 100-ka component (greater than $67 \mathrm{ka}$ ) has been filtered out. The parameter of obliquity is plotted for comparison (blue).

of EAM during the past $284 \mathrm{ka}$, which covers approximately 12 precession cycles or 7 obliquity cycles, can be used to analyse the time-dependent response to astronomical forcing. Modelling results are analysed using the modern calendar, thus, the "calendar effect", which means changes in the length of months and seasons that occur with the changing season of perihelion (Joussaume and Braconnot, 1997), is not taken into account in the current study.

Due to the delay of climate systems, the climate responses often lag the insolation forcing for a few months. For example, with the minimal insolation in December, the sea-level pressure maximum over land often occurs in January in our simulation. Hence, the simulated Siberian winter high (Asian summer low) during December-JanuaryFebruary (June-July-August) are employed as indicators of winter (summer) monsoon intensity and the in-phase December (June) insolation is chosen for comparison. Spatial domains of pressure cells are defined as follows: Siberian High: $30-70^{\circ} \mathrm{N}, 60-130^{\circ} \mathrm{E}$, Asian Low: $25-40^{\circ} \mathrm{N}, 70-$ $110^{\circ} \mathrm{E}$. The composite differences are defined on the precession and obliquity bands, respectively, as the averages between (1) the average of ten model years with minimal precession (PL, maximal insolation in boreal summer) minus those with maximal precession $(\mathrm{PH}$, minimal insolation in boreal summer) in each precession cycle; (2) the average of ten model years with maximal obliquity (TH, maximal insolation) minus those with minimal obliquity (TL, minimal insolation) in each obliquity cycle.

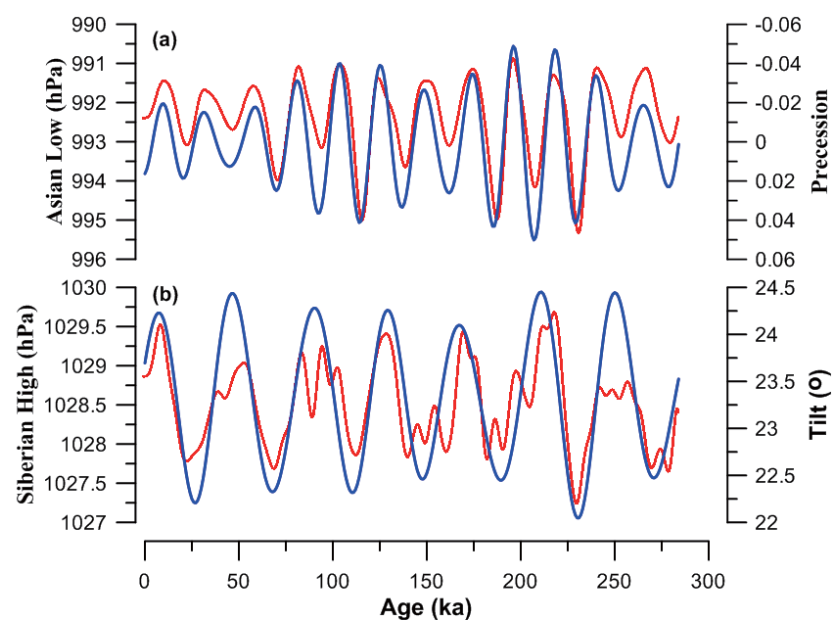

Fig. 3. Simulated time-dependent responses of East Asian summer and winter monsoons during the past $284 \mathrm{ka}$. The monsoon indices are defined as the averaged sea-level pressure for the Asian Low region $\left(25-40^{\circ} \mathrm{N}, 70-110^{\circ} \mathrm{E}\right)$ in boreal summer (JJA) and for the Siberian High region $\left(30-70^{\circ} \mathrm{N}, 60-130^{\circ} \mathrm{E}\right.$ ) in boreal winter (DJF), respectively. The components with periods of less than $10 \mathrm{ka}$ have been filtered out.

\section{EAM responses to astronomical forcing}

\subsection{Time-dependent responses}

The responses of the East Asian summer and winter monsoons are shown in the time series of climatic proxies from geological records (Fig. 2). During the past $224 \mathrm{ka}$, the stalagmite $\delta^{18} \mathrm{O}$ values, considered as the proxy of the summer monsoonal precipitation, change nearly synchronously with precession, revealing an obvious 20-ka periodicity (Fig. 2a). Although a phase lag of $2.9 \mathrm{ka}$ between precession and this monsoon proxy is proposed (Clemens et al., 2010), the approximate in-phase relation still supports the hypothesis that the subtropical summer monsoon systems respond directly to precession-dominated changes in NH insolation (Kutzbach, 1981) and the phase lag might primarily result from the thermal inertia of climate system. On the precession scale, stronger summer monsoon is found to appear with the maximal summer insolation. Different from the $\delta^{18} \mathrm{O}$ values, however, three GS variations do not follow the precession well and only a weak precession signal is visibly detected. In contrast, the GS records vary more synchronously with the obliquity (Fig. 2b), with a period of about 40-ka, which indicates that the development of the winter monsoon might differ from that of the summer monsoon.

Similar responses with the geological records are also detected in the summer/winter monsoon indices during the period of our simulation (Fig. 3). In summer, a dominant 20-ka precession cycle is observed in the variation of Asian low pressure (Fig. 3a), which is consistent with the local insolation. The approximately out-of-phase relation indicates 
Table 1. Variance percentages of astronomical components for both geological climatic proxies and model simulated indices of East Asian summer and winter monsoons (precession component: 18-25 ka bandpass-filtered; obliquity component: 33-50 ka bandpass-filtered). The grain size data from Jingyuan (J)/Xifeng-Changwu (X)/Zhaojiachuan $(\mathrm{Z})$ sections are respectively shown for winter monsoon. The referenced $30^{\circ} \mathrm{N}$ June $\left(50^{\circ} \mathrm{N}\right.$ December) insolation for summer (winter) monsoon is also included. See more details in the text.

\begin{tabular}{lll}
\hline EAM summer (winter) & Precession & Obliquity \\
\hline Geological proxies (winter: J/X/Z) & $52 \%\left(31 \% \mathrm{a} / 25 \% \mathrm{a} / 14 \%^{\mathrm{a}}\right)$ & $11 \%\left(52 \% \mathrm{a} / 51 \%^{\mathrm{a}} / 57 \%^{\mathrm{a}}\right)$ \\
Simulated indices & $82 \%(17 \%)$ & $0.0^{\mathrm{b}}(32 \%)$ \\
Local insolation & $92 \%(46 \%)$ & $3 \%(35 \%)$ \\
\hline
\end{tabular}

a 100-ka eccentricity component (greater than 67-ka) has been filtered out.

b Not significant at 0.9 confidence level.
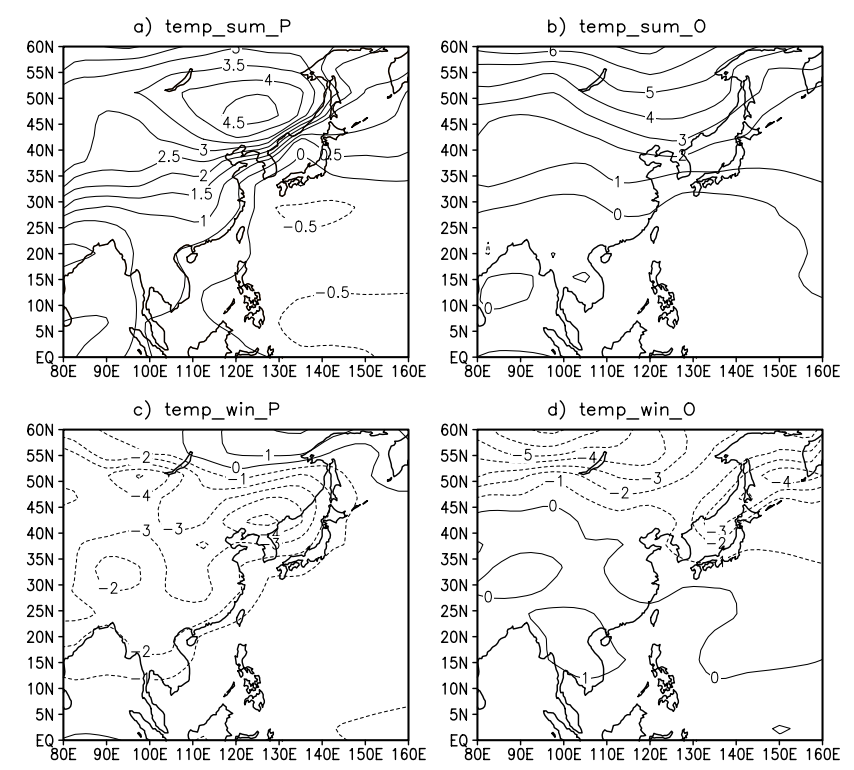

Fig. 4. Composite differences for surface air temperature $\left({ }^{\circ} \mathrm{C}\right)$ over East Asia on the precession (left, PL-PH) and obliquity (right, THTL) bands: (a, b) summer (JJA); (c, d) winter (DJF). See more in the text.

that the intensified Asian low pressure system corresponds to stronger local insolation at the precession band which tends to induce a strengthened ocean-land thermal difference. Despite the fact that the 20-ka cycle is still a little visible, the winter monsoon index is dominated by the 40-ka obliquity forcing (Fig. 3b).

Variance percentages of different astronomical components for both geological proxies and simulated monsoon index are presented in Table 1. The variability of Asian summer monsoon is dominated by the precession forcing, reaching fractions of $52 \%$ and $82 \%$, respectively, for geological proxies and simulated indices, which is consistent with the referenced $30^{\circ} \mathrm{N}$ June insolation (92\%). In boreal winter, precession can still control the variability of $50^{\circ} \mathrm{N}$ insolation (46\%) although the contribution from obliquity significantly increases $(35 \%)$. But a larger variance of
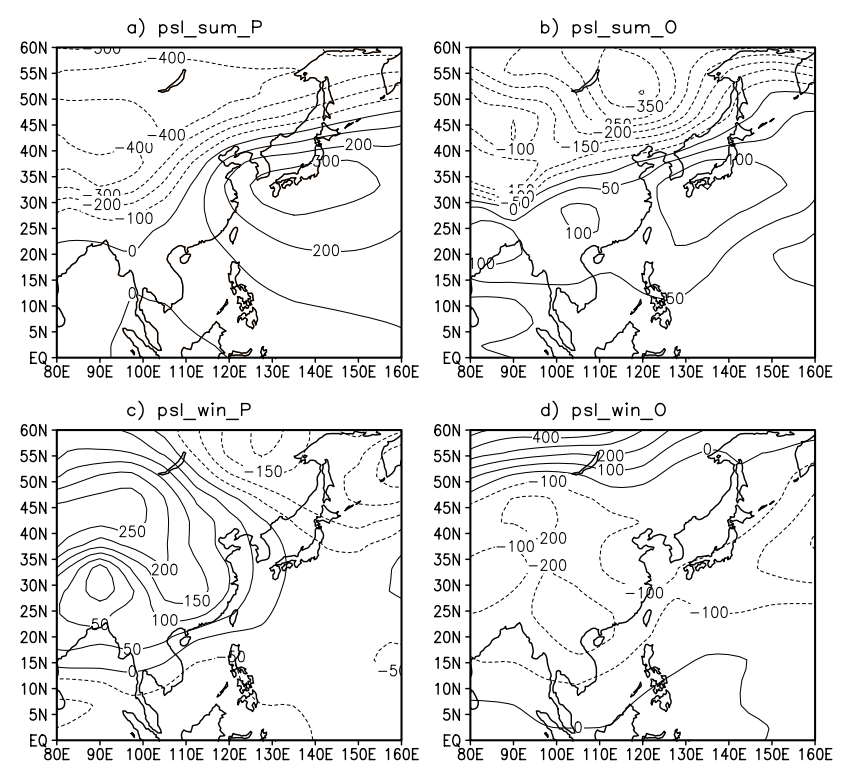

Fig. 5. Same as Fig. 3, but for sea-level pressure (hPa).

obliquity component consistently indicate more contribution from obliquity than precession in the Asian winter monsoon variability, which differs from local insolation. Thus, the response of East Asian winter monsoon is quite different from that of the summer monsoon, which is primarily influenced by the obliquity forcing.

\subsection{Composite differences}

The distinct responses of EAM to astronomical forcings are illustrated by the composite differences for the surface air temperature (Fig. 4), sea level pressure (SLP, Fig. 5), surface wind (Fig. 6) and precipitation rate (Fig. 7) during boreal summer (JJA) and winter (DJF) at precession and obliquity bands.

With an increase in the summer insolation (corresponding to decreased precession), the difference of precession composites of surface air temperature shows that a cold anomaly of $0.5^{\circ} \mathrm{C}$ is exhibited over the subtropical Pacific in boreal 

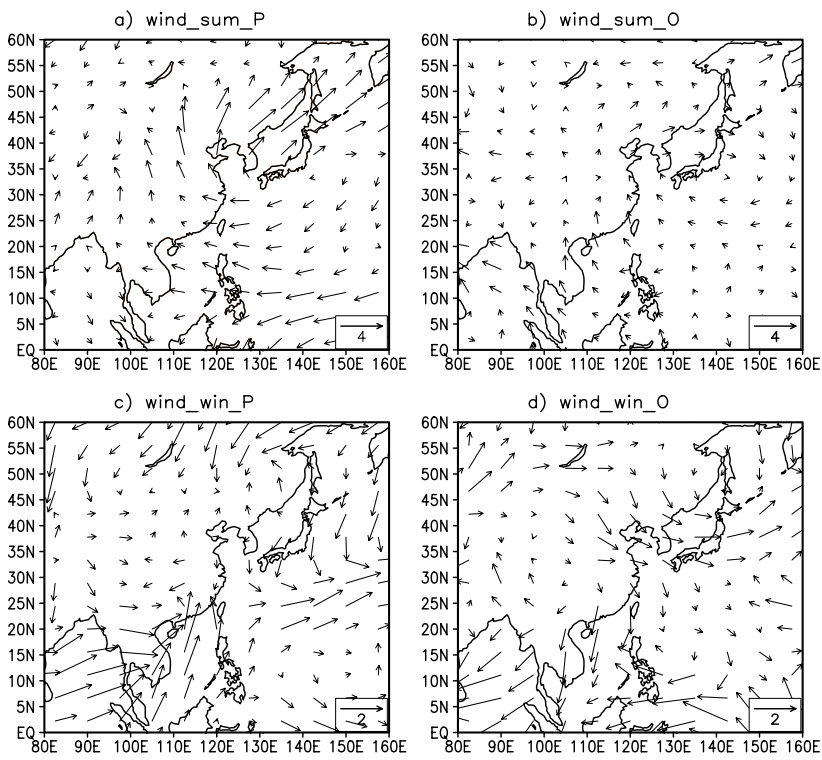

Fig. 6. Same as Fig. 3, but for surface wind vectors $\left(\mathrm{m} \mathrm{s}^{-1}\right)$.

summer (Fig. 4a). However, the surface air temperature increases by about $1{ }^{\circ} \mathrm{C}$ over the East Asian continent, with a maximum of up to $4{ }^{\circ} \mathrm{C}$ over Far East region, which significantly intensify the ocean-land thermal contrast over East Asia. In boreal winter, the monsoon response becomes distinctly converse. The air temperature is reduced by $2{ }^{\circ} \mathrm{C}$ on the mid-latitude land and the cooling is more significant over land than the ocean (Fig. 4c). In the obliquity composites, a reverse pattern is shown in the responses during summer and winter that the summer/winter temperature remarkably increases/decreases in the high latitudes while the change is less significant in the tropics (Fig. $4 \mathrm{~b}$ and d). Here we should note that the composites can not represent purely the behaviours of the temperature responding to one astronomical forcing, since we can not totally exclude the impact from the other.

Following the surface air temperature changes, the SLP also varies as a result of intensified land-ocean thermal contrast in the precession composites (Fig. 5a and c). The composite differences of SLP show that two prominent pressure anomalies occur over East Asian monsoon region. In boreal summer, a low SLP anomaly is located on the continent where the surface temperature is remarkably enhanced. The other high pressure anomaly develops over the ocean with anomalous surface wind divergence (Fig. 5a). In obliquity composites, the patterns of SLP changes also correspond well to that of surface temperature. The SLP over the high latitudes has significantly reduced/enhanced (Fig. 5b and d) due to the surface warming/cooling (Fig. $4 \mathrm{~b}$ and d).

In response to the strengthened SLP difference, the southeasterly surface wind has obviously been intensified by about $4 \mathrm{~m} \mathrm{~s}^{-1}$ over Eastern China when the summer insolation
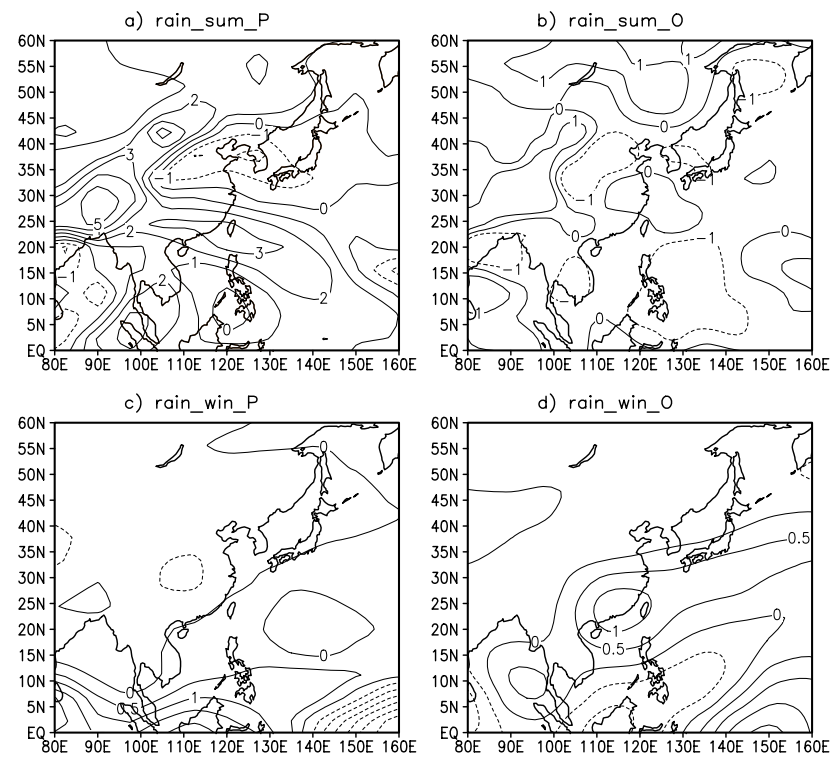

Fig. 7. Same as Fig. 3, but for precipitation rate $\left(\mathrm{mm} \mathrm{d}^{-1}\right)$.

reaches its peak on the precession band (Fig. 6a), which supports a linear response of the summer monsoon system to precession and associated temperature changes. However, the summer monsoon does not change significantly with the increasing obliquity (Fig. 6b). In boreal winter, the intensified high pressure cells over high latitudes induce stronger winter monsoons, represented by intensified northwesterly wind over Northeastern China, however, the monsoon response is more significant in the obliquity composites than precession (Fig. 6c and d). The summer precipitation increases by about $2 \mathrm{~mm} \mathrm{~d}^{-1}$ over Southeastern China for the precession composites as a result of an intensified monsoon system (Fig. 7a). In boreal winter, different from the precession composites (Fig. 7c), the monsoon system notably enhances and moves southward in the obliquity composites and brings plenty of frontal rainfall to southeastern China (Fig. 7d), appealing the importance of obliquity in the evolution of winter monsoon.

\section{Proposed mechanisms}

As shown above, the East Asian summer and winter monsoons exert distinct responses to astronomical forcings. The summer monsoon is no doubt predominantly driven by the precession, which supports the idea that the tropical/subtropical summer monsoon is controlled by the local insolation (Figs. 3a and 8). The larger insolation enhances the regional land-ocean thermal contrast and, thus, induces a stronger summer monsoon. However, the response of winter monsoon is quite different, exhibiting a more obvious 40 ka period than 20-ka period, suggesting more influences from 


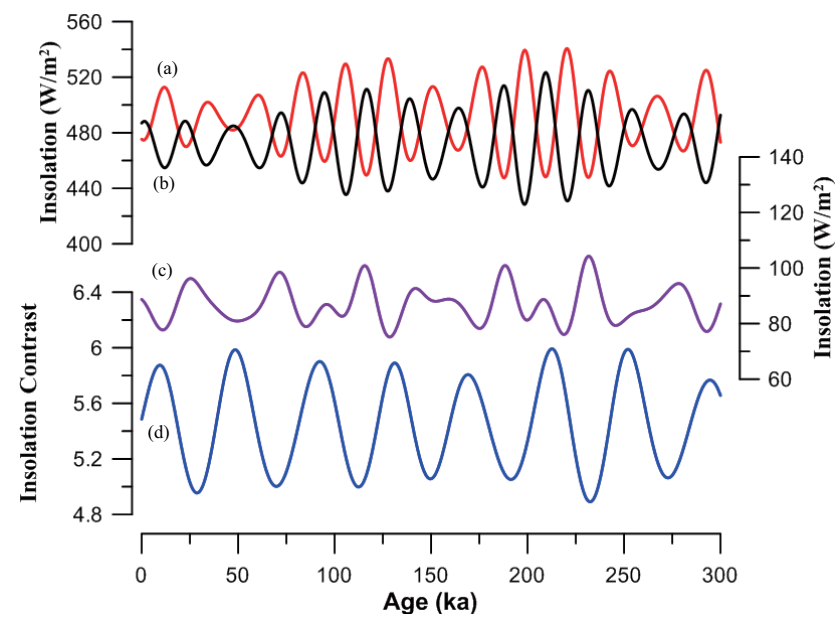

Fig. 8. Orbital insolation: (a) $30^{\circ} \mathrm{N}$ June insolation (red); (b) $20^{\circ} \mathrm{S}$ December insolation (black); (c) $50^{\circ} \mathrm{N}$ December insolation (purple); (d) ratio between (b) and (c) (blue). The insolation values are calculated by Berger (1978).

obliquity. In the following, we try to propose possible mechanisms for such obliquity-controlled winter monsoon.

It is clear that precession enhances the seasonal contrast in one hemisphere and controls the major changes in solar radiation over each latitude of the earth. Different from the dominance of precession in the tropical insolation, the contribution from obliquity increases in the high-latitude areas (Fig. 8). For example, precession can explain about $92 \%$ of the variability of the $30^{\circ} \mathrm{N}$ June insolation (Table 1). But for the $50^{\circ} \mathrm{N}$ June insolation, the fraction of precession decreases to $46 \%$ and that of obliquity increases to $35 \%$. Compared with the low pressure centre in summer, the location of high pressure cell of the winter monsoon system moves northward. The zonal ocean-land thermal contrast led by $50^{\circ} \mathrm{N}$ insolation has certainly affected the development of the Siberian High and induces a larger contribution from obliquity on the winter monsoon system (Fig. 8). However, other factors are still required to explain why stronger obliquity signals are detected rather than precession in the winter monsoon response.

We propose the distinct effect of obliquity parameter on insolation that leads to the remarkable 40-ka signals. Although precession controls the variability of daily insolation, obliquity forcing determines the meridional insolation differences. Physically, with the southward shift of ITCZ in boreal winter, more solar radiation at the low latitudes of the southern ocean leads to an upward airflow and that produces the Australian Low. The thermal-induced cross-equatorial meridional circulation, with a strong downward current over Eurasian continent, may substantially affect the development of the Siberian High. Thus, the ratio of insolations at $20^{\circ} \mathrm{S}$ and $50^{\circ} \mathrm{N}$ (approximately the centre of Australian Low and Siberian High, respectively) is considered here as an indicator for the intensity of meridional circulation. This index is a) omega_win_Omin

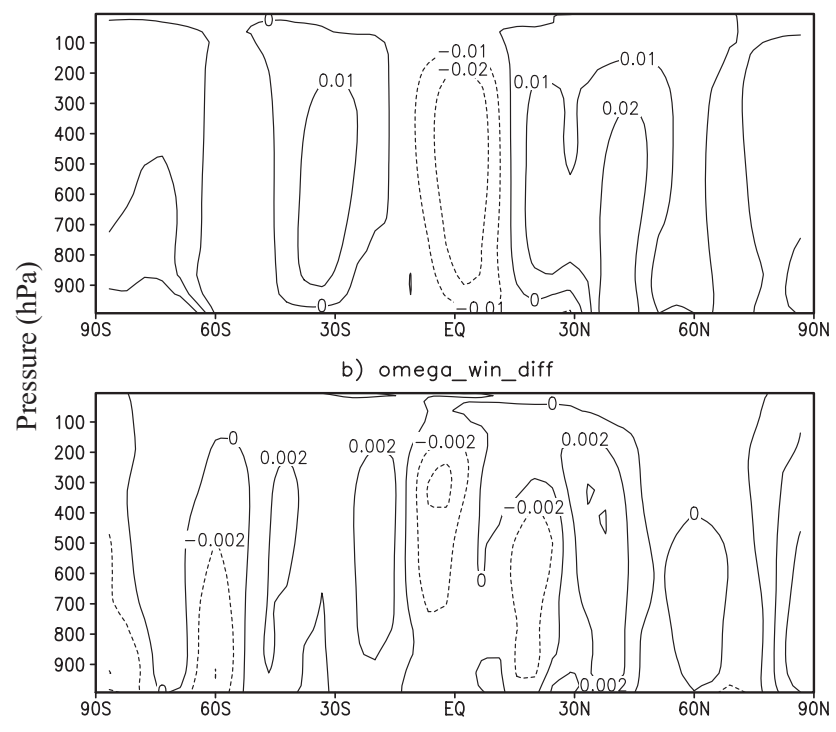

Fig. 9. The simulated TL composite of vertical velocity $\left(\mathrm{Pa} \mathrm{s}^{-1}\right)$ in boreal winter averaged $80-150^{\circ} \mathrm{E}$ (a) and the difference between TH and TL (b).

found to vary in a period of $40 \mathrm{ka}$, consistent with the response of the Siberian High (Figs. 3b and 8).

In the modelling results, we can also observe a significant response of meridional circulation in the obliquity composites (Fig. 9). In the TH composite, the cross-equatorial circulation with a downward airstream over the Siberian region is intensified compared with the TL composite, supporting that our explanations should be reasonable. Therefore, besides the local insolation forcing, the large-scale crossequatorial circulation, which results from the meridional insolation contrast, also play an important role in the Asian winter monsoon. Similar to our results, a previous study also indicated that obliquity-driven differential heating between low and high latitudes, which controls the poleward flux of heat and moisture, may exert the dominant control on highlatitude climates (Raymo and Nisancioglu, 2003). Certainly, we can not totally exclude the role of total irradiation, also controlled by obliquity, on the East Asian monsoon. But based on our results, the meridional insolation contrast is no doubt preferred in explaining such remarkable obliquity cycles in the winter monsoon. Further, various climatic processes, e.g., vegetation (Tuenter et al., 2005) and sea ice (Yin and Berger, 2011), might also impose their potential feedbacks, not discussed in this study, on the direct impacts of astronomical forcings on the monsoon evolution. 


\section{Conclusions}

Newly developed climatic proxies from caves in Central China and the Chinese Loess Plateau and an indicator of the EAM intensity from a $284 \mathrm{ka}$ long-term transient GCM simulation have both revealed distinct responses of East Asian summer and winter monsoons to astronomical forcing, at least in the past two or three glacial cycles. In boreal winter, other than the generally-accepted importance of local insolation, the atmospheric circulation driven by meridional thermal contrast also has a substantial influence on the Siberian High and then leads to an obliquity-periodic monsoon evolution. The Asian summer monsoon, however, is mainly controlled by the precession-induced local insolation and the corresponding ocean-land temperature contrast. Hence, these distinct responses imply that obliquity-driven meridional thermal contrast, so far not mentioned before, may have significant influence especially on the evolution of the East Asian winter monsoon.

Acknowledgements. The authors thank A. L. Berger and the anonymous reviewer for their constructive comments. This study is jointly supported by NSFC (41075067), CAS(KZCX2-EW114), the 973 Programme (2010CB833406) and NSFC (40825008).

Edited by: D.-D. Rousseau

\section{References}

An, Z. S.: The history and variability of the East Asian paleomonsoon climate, Quaternary Sci. Rev., 19, 171-187, 2000.

An, Z. S., Kukla, G., Porter, S. C., and Xiao, J. L.: Magnetic susceptibility evidence of monsoon variation on the Loess Plateau of Central China during the last 130000 years, Quaternary Res., 36, 29-36, 1991.

An, Z. S., Kutzbach, J. E., Prell, W. L., and Porter, S. C.: Evolution of Asian monsoons and phased uplift of the Himalaya-Tibetan Plateau since late Miocene times, Nature, 411, 62-66, 2001.

Berger, A. L.: Long-term variations of caloric insolation resulting from the Earth's orbital elements, Quaternary Res., 9, 139-167, 1978.

Berger, A. L.: Milankovitch theory and climate, Rev. Geophys., 26, 624-657, 1988.

Berger, A., Loutre, M.-F., and Yin, Q.: Total irradiation during any time interval of the year using elliptic integrals, Quaternary Sci. Rev., 29, 1968-1982, 2010.

Braconnot, P., Loutre, M. F., Dong, B., Joussaume, S., and Valdes, P.: How the simulated change in monsoon at $6 \mathrm{ka} \mathrm{BP}$ is related to the simulation of the modern climate: results from the Paleoclimate Modeling Intercomparison Project, Clim. Dynam., 19, 107-121, 2002.

Clemens, S. C. and Prell, W. L.: A 350000 year summer monsoon multi-proxy stack from the Owen Ridge, Northern Arabian Sea, Mar. Geol., 201, 35-51, 2003.

Clemens, S. C., Prell, W. L., and Sun, Y. B.: Orbital-scale timing and mechanisms driving late Pleistocene Indo-Asian summer monsoons: reinterpreting cave speleothem $\delta^{18} \mathrm{O}$, Paleoceanography, 25, PA4207, doi:10.1029/2010PA001926, 2010.
Ding, Z. L., Rutter, N. W., Han, J. T., and Liu, T. S.: A coupled environmental system formed at about 2.5 Ma over East Asia, Palaeogeogr. Palaeocl., 94, 223-242, 1992.

Ding, Z. L., Liu, T. S., Rutter, N. W., Yu, Z. W., Guo, Z. T., and Zhu, R. X.: Ice-volume forcing of East Asian winter monsoon variations in the past 800000 years, Quaternary Res., 44, 149159, 1995.

Guo, Z. T., Berger, A., Yin, Q. Z., and Qin, L.: Strong asymmetry of hemispheric climates during MIS-13 inferred from correlating China loess and Antarctica ice records, Clim. Past, 5, 21-31, doi:10.5194/cp-5-21-2009, 2009.

Hays, J. D., Imbrie, J., and Shackleton, N. J.: Variations in the Earth's orbit: pacemaker of the Ice Ages, Science, 194, 11211132, 1976.

Imbrie, J., Boyle, E. A., Clemens, S. C., Duffy, A., Howard, W. R., Kukla, G., Kutzbach, J., Martinson, D. G., McIntyre, A., Mix, A. C., Molfino, B., Morley, J. J., Peterson, L. C., Pisias, N. G., Prell, W. L., Raymo, M. E., Shackleton, N. J., and Toggweiler, J. R.: On the structure and origin of major glaciation cycles. 1. Linear responses to Milankovitch forcing, Paleoceanography, 7, 701-738, 1992.

Jackson, C. S. and Broccoli, A. J.: Orbital forcing of Arctic climate: mechanisms of climate response and implications for continental glaciation, Clim. Dynam., 21, 539-557, 2003.

Joussaume, S. and Braconnot, P.: Sensitivity of paleoclimate simulation results to season definition, J. Geophys. Res., 102, 19431956, 1997.

Kutzbach, J. E.: Monsoon climate of the early Holocene: climate experiment with Earth's orbital parameter for 9000 years ago, Science, 214, 59-61, 1981.

Kutzbach, J. E., Liu, X. D., Liu, Z. Y., and Chen, G. S.: Simulation of the evolutionary response of global summer monsoons to orbital forcing over the past 280000 years, Clim. Dynam., 30, 567-579, doi:10.1007/s00382-007-0308-z, 2007.

Liu, X. D. and Shi, Z. G.: Effect of precession on the Asian summer monsoon evolution: A systematic review, Chinese Sci. Bull., 54, 3720-3730, 2009.

Liu, Z., Otto-Bliesner, B., Kutzbach, J., Li, L., and Shields, C.: Coupled climate simulation of the evolution of global monsoons in the Holocene, J. Climate, 16, 2472-2490, 2003.

Liu, Z., Harrison, S. P., Kutzbach, J. E., and Otto-Bliesner, B.: Global monsoons in the mid-Holocene and oceanic feedback, Clim. Dynam., 22, 157-182, 2004.

Lorenz, S. J. and Lohmann, G.: Accelerated technique for Milankovitch type forcing in a coupled atmosphere-ocean circulation model: method and application for the Holocene, Clim. Dynam., 23, 727-743, 2004.

Porter, S. C. and An, Z. S.: Correlation between climate events in the North Atlantic and China during the last glaciation, Nature, 375, 305-308, 1995.

Raymo, M. E. and Nisancioglu, K.: The $41 \mathrm{kyr}$ world: Milankovitch's other unsolved mystery, Paleoceanography, 18, 1011, doi:10.1029/2002PA000791, 2003.

Sun, Y. B., Chen, J., Clemens, S. C., Liu, Q. S., Ji, J. F., and Tada, R.: East Asian monsoon variability recorded by a loess sequence from the Northwestern Chinese Loess Plateau, Geochem. Geophy. Geosy., 7, Q12Q02, doi:10.1029/2006GC001287, 2006a. 
Sun, Y. B., Clemens, S. C., An, Z. S., and Yu, Z. W.: Astronomical timescale and palaeoclimatic implication of stacked 3.6-Myr monsoon records from the Chinese Loess Plateau, Quaternary Sci. Res., 25, 33-48, 2006 b.

Tricot, Ch. and Berger, A. L.: Sensitivity of present-day climate to astronomical forcing, in: Lecture notes in earth science, edited by: Wanner, H. and Siegenthaler, U., Springer-Verlag, New York, 16, 132-152, 1988.

Tuenter, E., Weber, S. L., Hilgen, F. J., Lourens, L. J., and Ganopolski, A.: Simulation of climate phase lags in response to precession and obliquity forcing and the role of vegetation, Clim. Dynam., 24, 279-295, 2005.

Wang, B.: The Asian Monsoon, Springer Publishing Company, New York, 2006.

Wang, P. X., Clemens, S., Beaufort, L., Braconnot, P., Ganssen, G., Jian, Z., Kershaw, P., and Sarnthein, M.: Evolution and variability of the Asian monsoon system: state of the art and outstanding issues, Quaternary Sci. Rev., 24, 595-629, 2005.
Wang, Y. J., Cheng, H., Edwards, R. L., Kong, X., Shao, X., Chen, S., Wu, J., Jiang, X., Wang, X., and An, Z.: Millennialand orbital-scale changes in the East Asian monsoon over the past 224000 years, Nature, 451, 1090-1093, 2008.

Xiao, J. L., Zheng, H. B., and Zhao, H.: Variation of winter monsoon intensity on the Loess Plateau, Central China during the last 130000 years: evidences from grain size distribution, Quaternary Res., 31, 13-19, 1992.

Yin, Q. Z. and Berger, A. L.: Individual contribution of insolation and $\mathrm{CO}_{2}$ to the interglacial climates of the past 800,000 years, Clim. Dynam., doi:10.1007/s00382-011-1013-5, in press, 2011.

Yin, Q. Z., Berger, A., and Crucifix, M.: Individual and combined effects of ice sheets and precession on MIS-13 climate, Clim. Past, 5, 229-243, doi:10.5194/cp-5-229-2009, 2009.

Yuan, D. X., Cheng, H., Edwards, R. L., Dykoski, C. A., Kelly, M. J., Zhang, M., Qing, J., Lin, Y., Wang, Y., Wu, J., Dorale, J. A., An, Z., and Cai, Y.: Timing, duration, and transitions of the last interglacial Asian Monsoon, Science, 304, 575-578, 2004. 